\title{
ОКРЕМІ ПИТАННЯ ВІДНЕСЕННЯ ДОГОВОРІВ РЕЙСОВОГО ЧАРТЕРУ ТА ТАЙМ-ЧАРТЕРУ ДО ДОГОВОРУ МОРСЬКОГО ПЕРЕВЕЗЕННЯ В УKPAÏHI
}

Постановка проблеми. Морський транспорт традиційно виступає одним із ключових інструментів розвитку світової економіки та торгівлі. За даними спеціалізованої установи ООН - Міжнародної морської організації (MMO), натепер більше $80 \%$ світової торгівлі забезпечується за допомогою судноплавства. Судноплавство $€$ найбільш ефективним i рентабельним методом здійснення міжнародних перевезень більшості товарів [25]. Своєю чергою, одним із найбільш затребуваних способів реалізації морської перевезення вантажу виступає фрахтування судів.

Договори фрахтування судів називають чартерами, іноді використовують і термін чартер-партія (charterparty). У найзагальнішому вигляді чартер - це «договір між судновласником і фрахтувальником, за яким права на судно залежно від виду фрахтування повністю або частково переходять до фрахтувальника» [19, р. 171].

У Цивільному кодексі України (далі - ЦК України), а саме - у ст. 912 позначені лише загальні контури договору фрахтування та міститься відсилання до спеціального закону (у цьому випадку - до Кодексу торговельного мореплавства України (далі КТМ України)), відповідно до якого, зокрема, встановлюється форма договору фрахтування.

Проте законодавець не уточнив, що називається формою договору фрахтування. 3 одного боку, можна припустити, що формами договору фрахтування $€$ рейсовий чартер, тайм-чартер, бербоут-чартер і димайз-чартер. хоча, скоріше, це види договору фрахтування. 3 іншого боку, звернемо увагу на ст. 204 КТМ України, яка встановлює, що договір чартеру (фрахтування) повинен бути укладений у письмовій формі. Таким чином, форму договору фрахтування (чартеру) можна трактувати як його письмове або усне вираження. I нарешті, форма договору фрахтування може тлумачитися зокрема й як договір суборенди (ст. 206 КТМ України).

Аналіз останніх досліджень і публікацій, у яких започатковано розв'язання вказаної проблеми. Теоретичну основу дослідження склали наукові праці таких науковців, як A.I. Муранов, Д.Л. Давиденко, В.І. Борисова, І.В. Фатєєва, В.Л. Яроцький, Ч.Н. Азімов, М.М. Сібільов, В.І. Борисова, П.Ф. Коваль, Н.О. Алешугіна, Г.П. Андрєєва, О. В. Столярський, С.С. Бичкова, І.А. Бірюков, B.I. Бобрик та інші вчені. 
Мета статті - науковий аналіз загальних положень законодавства України з метою визначення окремих питань загальної класифікації видів договорів чартеру (фрахтування) та їх проформ.

Виклад основного матеріалу. Чартери здавна використовуються в практиці морського судноплавства, проте і сьогодні як у доктрині, так і на практиці немає єдиного розуміння їнього юридичного статусу. Деякі автори вносять плутанину, змішуючи різні види фрахтування, а іноді використовують абсолютно неприпустиму термінологію, наприклад «договір чартеру» $[14$, с. $7-10]$.

КТМ України виділяє два види договору фрахтування морського судна - договір фрахтування судна на час (тайм-чартер) і договір фрахтування судна без екіпажу (бербоут-чартер), положення про які містяться в главі I розділу VI KTM України. Водночас у зарубіжній доктрині чартери підрозділяються залежно від того, як фрахтується судно - на певний період чи на один або кілька рейсів [26]. У першому випадку йдеться про тайм-чартер (time-charter), у другому - про рейсовий чартер (voyage charter). Якщо за умовами тайм-чартеру судновласник передає судно в розпорядження фрахтувальника на обумовлений договором період фрахтування, то рейсовий чартер передбачає передачу судна для перевезення вантажу між визначеними портами.

В обох випадках судновласник зберігає контроль за комплектуванням екіпажу і управлінням судном, а також бере на себе зобов'язання забезпечити перевезення вантажу.

Третій вид договору фрахтування, відомий під назвами бербоут-чартеру (bareboat charter) i димайз-чартеру (demise charter), принципово відрізняється від двох вказаних вище. Бербоут-чартер і димайз-чартер, по суті, являють собою договір оренди судна. Втім, відразу обмовимося, що договір оренди морського судна значною мірою відрізняється від класичного договору оренди майна. Це зумовлено специфічними особливостями статусу морського судна і виконуваної ним діяльності $з$ морського перевезення вантажу.

Таким чином, усі використовувані натепер договори фрахтування судна можна розділити на три види: рейсовий чартер, тайм-чартер і бербоут-чартер (димайз-чартер).

Звісно ж, такий підхід відповідає усталеній практиці міжнародного торгового судноплавства. Так, в останні роки за кордоном побачили світ три фундаментальних праці, підготовлених визнаними авторитетами в галузі морського права, які присвячені практиці застосування саме трьох видів чартерів - рейсового чартеру, тайм-чартеру та бербоут-чартеру [20; $21 ; 22]$. Спроби виділити інші види договорів фрахтування суден (дейлі-чартер, слот-чартер тощо) навряд чи є обгрунтованими, оскільки вони не мають самостійного значення і є лише приватними випадками трьох вказаних вище видів чартерів.

Загалом же не можна не погодитися 3 британським науковцем Р. Граймом, який вважає, що «незважаючи на різні види договорів фрахтування, суть їх одна й та ж і полягає в тому, що судновласник надає своє судно для перевезення вантажу» [23, p. 80]. Крім того, «всі чартери, як правило, містять умову, згідно з якою судновласнику потрібно мати морехідне судно» [24, р. 563].

У практиці фрахтування сьогодні широко використовуються так звані проформи чартерів, що являють собою стандартні чартери, розроблені міжнародними організаціями (більшою частиною Балтійською i міжнародною морською радою - Baltic and International Maritime Council (BIMCO) [5], Федерацією національних асоціацій суднових брокерів i агентів (FONASBA) [6]) залежно від видів фрахтування, типів вантажу i сформованих напрямків вантажопо- 
токів. Проформи чартерів засновані на балансі інтересів .. фрахтувальників і судновласників. Їх застосування значною мірою спрощує процес фрахтування судів, коли немає необхідності детально погоджувати всі умови чартеру, а досить послатися на ту чи іншу його проформу і при необхідності внести взаємоприйнятні зміни і доповнення.

Рейсовим чартером називається договір між судновласником і фрахтувальником, що передбачає передачу всього судна або частини його вантажних приміщень для перевезення вантажу між визначеними портами.

За доставку вантажу фрахтувальник сплачує судновласнику фрахт, розмір якого формується на основі ставки фрахту з урахуванням кон'юнктури світового фрахтового ринку. Ставка або узгоджується за одиницю вантажу (тонна, куб. м тощо), або обумовлюється в розмірі певної суми (люмпсум). Зазвичай розрізняють два типу фрахтування судів по рейсових чартерах: фрахтування на один рейс (single voyage charter) і на ряд послідовних рейсів (consecutive voyages charter).

Договір морського перевезення вантажу може бути укладений як із умовою надання для морського перевезення вантажу всього судна, його частини або певних суднових приміщень (КТМ України позначає такий договір як чартер), так і без такої умови. Конвенція ООН про морське перевезення вантажів від 31 березня 1978 року (Гамбурзькі правила) [4; 10] визначає договір морського перевезення як будь-який договір, відповідно до якого перевізник за сплату фрахту зобов'язується перевезти вантаж морем 3 одного порту в інший (ч. 6 ст. 1).

Таким чином, із визначення договору морського перевезення вантажу, закріпленого в українському законодавстві (КТМ України) і в міжнародному морському праві (Гамбурзькі правила), абсолютно очевидно, що рейсовий чартер за своєю юридичною природою є договором морського перевезення. Цей висновок підтверджується позиціями відомих фахівців в області приватного морського права.

Н.В. Воронець у своєму дослідженні визначає, що чартером слід називати «договір морського перевезення, за яким одна сторона (фрахтівник) зобов'язується подати судно в порт навантаження i перевезти з умовою надання всього судна, його частини чи певних суднових приміщень вантаж в порт призначення, де видати його одержувачу, а інша сторона (фрахтувальник) зобов'язується забезпечити пред'явлення вантажу і сплатити за його перевезення встановлену плату» [8]. Своєю чергою, Д.А. Рябкін пропонує спрощене визначення чартеру, який слід розуміти як «договірну форму морських перевезень вантажів у нерегулярному судноплавстві» [16, с. 218]. B.А. Попов та О.О. Рубан також вважають, що «договір чартеру (фрахтування) представляє не що інше, як договір перевезення» [15, с. 92-94].

В українському законодавстві відображено вказане бачення юридичної природи рейсового чартеру, зокрема у ст. 134 КТМ України: «документом, що підтверджує наявність і зміст договору морського перевезення вантажу, є, зокрема, рейсовий чартер, якщо він передбачає умову надання для перевезення всього судна, його частини або окремих суднових приміщень» [2].

Таким чином, можна резюмувати, що по суті рейсовий чартер є договором морського перевезення вантажу, які передбачають надання для морського перевезення вантажу всього судна, частини його або певних суднових приміщень. Судновласник (фрахтувальник) у цьому випадку зберігає повний контроль над судном і його екіпажем без будь-яких вилучень на користь фрахтувальника. Проформою рейсового чартеру, що 
набула широкого поширення в практиці міжнародного торговельного судноплавства, $€$ загальний універсальний чартер «Дженкон» (General Contract), схвалений ВIMCO.

Якщо за умовами рейсового чартеру належний судновласнику фрахт виплачується фрахтувальником за перевезення вантажу, то оплата по тайм-чартеру пов'язана виключно з періодом, протягом якого судно знаходиться в розпорядженні фрахтувальника [11]. Українське законодавство в частині, що стосується тайм-чартеру, загалом засновано на нормах міжнародного приватного морського права. Згідно зі ст. 203 КТМ України за договором фрахтування судна на час (тайм-чартеру) судновласник зобов'язується за обумовлену плату (фрахт) надати фрахтувальнику судно і послуги членів екіпажу судна в користування на певний термін для перевезень вантажів, пасажирів або для інших цілей торгового мореплавання [2]. До інших цілей торгового мореплавання КТM України відносить рибальство, морські ресурсні дослідження, розвідку та розробку мінеральних та інших неживих ресурсів морського дна та його надр, лоцманську і криголамну проводки, пошукові та рятувальні операції, підйом затонулого в морі майна, гідротехнічні, підводно-технічні та інші подібні роботи, санітарний, карантинний та інший контроль, захист і збереження морського середовища, морські наукові дослідження, навчальні, спортивні та культурні цілі. Причому цей перелік не є вичерпним, до цілей торгового мореплавання можуть бути уналежнені й інші види діяльності.

Таким чином, бачимо, що тайм-чартер може бути використаний не тільки для перевезень, а й для широкого кола видів діяльності, пов'язаних із торговельним мореплавством.

Проблема полягає в тому, що до сьогодні як у доктрині, так і на практиці немає єдиного розуміння юридичної природи тайм-чартеру.
Суть суперечок зводиться до того, чи $€$ тайм-чартер договором оренди (найму) судна, чи ми маємо справу з договором морського перевезення.

3 визначення тайм-чартеру, даного в КТМ України, випливають такі вельми важливі висновки. Судновласник надає фрахтувальнику в користування на певний період не тільки судно, але ще й послуги екіпажу. Причому це характерна відмітна ознака тайм-чартеру. Виключення послуг екіпажу відразу ж змінює сутність договору фрахтування, і тайм-чартер перетворюється на інший вид договору фрахтування, наприклад, на бербоут-чартер. Таким чином, у тайм-чартері судно і його екіпаж виступають як єдине ціле. У цьому принципова відмінність тайм-чартеру від звичайного договору оренди.

Згідно зі ст. 759 ЦК України за договором оренди (майнового найму) орендодавець (наймодавець) зобов'язується надати орендарю (наймачу) майно за плату в тимчасове володіння і користування або у тимчасове користування [1]. Як бачимо, за договором оренди передається тільки майно, а тайм-чартер передбачає ще й передачу послуг екіпажу з управління і технічної експлуатації судна. Крім того, на відміну від договору оренди, тайм-чартер містить виключно важливе положення, яке передбачає, що судновласник продовжує зберігати контроль як за судном, так і за його екіпажем. Судновласник зобов'язаний не тільки привести судно в морехідне стан до моменту його передачі фрахтувальнику, але після передачі судна фрахтувальнику судновласник продовжує нести обов'язок протягом усього терміну дії тайм-чартеру з підтримки судна в морехідному стані. Крім того, судновласник зобов'язаний нести витрати зі страхування судна i своєї відповідальності, а також 3 утримання членів екіпажу судна. Капітан судна й очолюваний ним екіпаж за умовами тайм-чартеру перебувають у подвійному підпорядкуванні. 
3 питань управління (включаючи судноводіння, внутрішній розпорядок на судні) капітан і екіпаж підкоряються судновласнику. Водночас для капітана та інших членів екіпажу обов'язкові розпорядження фрахтувальника, що стосуються комерційної експлуатації судна.

Ще одна принципова відмінність між договором оренди і тайм-чартером полягає в розподілі отриманих доходів. Згідно зі ст. 775 ЦК України плоди, продукція та доходи, отримані орендарем у результаті використання орендованого майна відповідно до договору, $є$ його власністю. Водночас відповідно до умов тайм-чартеру доходи, отримані в результаті користування зафрахтованим судном і послугами членів його екіпажу, є власністю фрахтувальника, за винятком доходів, отриманих від рятування. Відповідно до ст. 214 КТМ України винагорода, що належить судну за послуги 3 рятування, надані до закінчення діï тайм-чартеру, розподіляється в рівних частках між судновласником i фрахтувальником за вирахуванням витрат на рятування i належної екіпажу судна частки винагороди.

I нарешті, важлива особливість тайм-чартеру полягає в тому, що фрахтувальник може користуватися судном і послугами його екіпажу тільки в рамках, визначених умовами тайм-чартеру. Спроби прирівняти тайм-чартер до договору оренди вихолощують його сенс і мету. Укладення договору фрахтування судна натепер перестало бути самоціллю і зрештою слугує тільки одному використанню судна для цілей торгового мореплавання.

Ряд авторів, посилаючись на ЦК України, розглядають тайм-чартер як різновид договору оренди транспортних засобів із наданням послуг 3 управління та технічної експлуатації [17]. Така позиція присутня і в авторів українського підручника з міжнародного приватного права, які вважають, що тайм-чартер належить «у термінах загальногромадянського законодавства до договорів оренди транспортних засобів» [12].

Такий підхід має підстави, якщо мова йде про інші види перевезень, наприклад повітряних. Тут можна погодитися, що «кваліфікація договору фрахтування в якості орендного типу найбільшою мірою відповідає як його змісту, так і дійсному стану, що склався в області його правового регулювання» [7]. Однак щодо морських перевезень юридична природа тайм-чартеру принципово інша.

Якщо тайм-чартер не є договором оренди, то виникає питання - чи не належить він до договорів морського перевезення вантажу? Відповідь на це питання залежить від того, для яких цілей фрахтується судно по тайм-чартеру. Якщо судно фрахтується для перевезення вантажу, то, поза всяким сумнівом, ми маємо справу з різновидом договору морського перевезення вантажу. Це зумовлено тим, що в такому випадку укладання договору фрахтування судна на певний час зрештою слугує тільки одному перевезти вантаж з пункту завантаження до пункту призначення.

Якщо ж судно фрахтується по тайм-чартеру для інших цілей, наприклад, для проведення морських наукових досліджень і тощо, то в такому випадку тайм-чартер є самостійним видом договору (договір sui generis).

Цікавою $є$ позиція українських фахівців із вказаного питання. Так, автори Коментаря до Кодексу торговельного мореплавства України, аналізуючи ст. 133 «Поняття договору морського перевезення вантажу» [3, 13], пишуть: «Сторони договору фрахтування не можуть бути водночас сторонами договору перевезення, оскільки це призведе до тотожності різних за змістом зобов'язань. Навіть якщо правовідносини 3 фрахтування морського судна передують правовідносинам із перевезення вантажу, сторонами в договорі перевезення будуть перевізник, вантажовідправник 
і вантажоодержувач, тому що вони мають відмінні від договору фрахтування зобов'язання. До того ж, договір фрахтування має свій предмет, зміст, склад сторін (двосторонній) і ніяк не повинен впливати на інший самостійний вид договору, який застосовується в сфері торговельного мореплавства - договір морського перевезення вантажу. Таким чином, два договори - перевезення і фрахтування - не можуть поєднуватися в одному, бо тим самим змішується їхня предметна ознака, відпадає критерій розмежування і стає неможливим пояснити, чому вони знайшли своє закріплення в різних розділах КТМ України [2]». Очевидно, що автори Коментаря вважають тайм-чартер самостійним видом договору.

Із зазначеною точкою зору можна погодитися лише частково; вона справедлива, якщо мова йде про тайм-чартер, укладений не для перевезення вантажу, а для інших цілей. Якщо ж ми маємо справу з тайм-чартером, укладеним для перевезення вантажу, то у згаданому контексті термін «договір морського перевезення» є родовим і цим поняттям охоплюється зокрема й договір фрахтування судна на час для перевезення вантажу. Таким чином, за змістом ст. 133 КТМ України, тайм-чартер є договором морського перевезення вантажу. I йдеться зовсім не про «тотожності різних за змістом зобов'язань», як пишуть автори Коментаря, а про те, що тайм-чартер є різновидом договору морського перевезення.

Суперечка про те, є тайм-чартер договором оренди чи морського перевезення, не носить чисто теоретичного характеру, вона має серйозні й далекосяжні практичні наслідки.

Як уже зазначалося, якщо судно фрахтується по тайм-чартеру для перевезення вантажу, то тайм-чартер є різновидом договору морського перевезення вантажу. Якщо ж судно фрахтується по тайм-чартеру для інших цілей, тоді тайм-чартер є самостійним видом договору (договір sui generis). Однак і в тому, і в іншому випадку «тимчасово здійснюється подвійне володіння (співволодіння) судном».

Основною проформою тайм-чартеру, що використовується сьогодні, виступає Універсальний чартер «BALTIME» (Baltic and International Maritime Council Time-charter-party), розроблений і схвалений ВIMCO.

У статті визначається, щзо морський транспорт традиційно виступає одним із ключових інструментів розвитку світової економіки та торгівлі. За даними спеціалізованої установи ООН Міннародної морської організащї, натепер більше 80 відсотків світової торгівлі забезпечується за допомогою судноплавства. Судноплавство є найбільш ефективним $i$ рентабельним методом здійснення міжнародних перевезень більшості товарів. Своєю чергою, одним iз найбільи затребуваних способів реалізації морської перевезення вантажу виступае фрахтування суден.

Договори фрахтування суден називають чартерами, іноді використовують $i$ термін чартер-парmiя (charter-party). У найзагальнішому вигляді иартер - це «договір між судновласником $і$ фрахтувальником, за яким права на судно залежно від виду фрахтування повністю або частково переходять до фрахтувальника».

У Цивільному кодексі України (cm. 912 ЦК України) позначені лише загальні контури договору фрахтування та міститься відсилання до спеціального закону (у вказаному випадку - до Кодексу торговельного мореплавства України), відповідно до якого, зокрема, встановлюеться форма договору фрахтування. 
Проте законодавеиь не уточнив, що називається формою договору фрахтування. 3 одного боку, можна припустити, що формами договору фрахтування $є$ рейсовий чартер, тайм-чартер, бербоут-чартер i димайз-чартер. хоча, скоріше, ие види договору фрахтування. 3 іншого боку, звернемо увагу на cm. 204 Кодексу торговельного мореплавства Украӥни, яка встановлює, що договір чартеру (фрахтування) повинен бути укладении у письмовій формі. Таким чином, форму договору фрахтування (чартеру) можна трактувати як його письмове або усне вираження. I нарешті, форма договору фрахтування може тлумачитися зокрема й як договір суборенди (cm. 206 Кодексу торговельного мореплавства України).

Ключові слова: цивільно-правовий договір, договір чартеру (фрахтування), тайм-чартер, рейсовий чартер, договір перевезення, договір морського перевезення, транспорт, морський транспорт, пасажир.

Kolodin A. Regarding certain issues of classifying voyage charter and time charter agreements to the contract of sea transportation in Ukraine

The proposed article defines that maritime transport has traditionally been one of the key tools for the development of the world economy and trade. According to a specialized agency of the United Nations - the International Maritime Organization, currently, more than 80 percent of world trade is provided by shipping. Shipping is the most efficient and cost-effective method of international transportation of most goods. In turn, one of the most popular ways to implement sea freight is ship chartering.

Court chartering agreements are called charters, sometimes using the term charter-party. In its most general form, a charter is an "agreement between a shipowner and a charterer under which the rights to a vessel, depending on the type of chartering, are transferred in whole or in part to the charterer."

$$
\text { The Civil Code of Ukraine }
$$
(Article 912 of the Civil Code of Ukraine) indicates only the general outlines of the charter agreement and contains a reference to a special law (in this case - Code of Merchant Shipping (CMS) of Ukraine), according to which, in particular, the form of the charter agreement is established.

However, the legislator did not specify what is meant by the form of a charter agreement. On the one hand, it can be assumed that the forms of chartering agreement are voyage charter, time charter, bareboat charter, and demise charter, although, rather, these are types of chartering agreement. On the other hand, pay attention to Art. 204 CMS of Ukraine establishes that the charter agreement (chartering) has to be concluded in writing form. Thus, the form of a charter agreement (charter) can be understood as its written or oral expression. Finally, the form of a charter agreement may include a sublease agreement (Article 206 of the CMS of Ukraine).

Key words: civil-legal agreement, charter agreement (chartering), time charter, voyage charter, the transportation agreement, the sea transportation agreement, transport, sea transport, passenger.

\section{Література}

1. Цивільний кодекс України : Закон України від 16 січня 2003 р. № 435-IV / Верховна Рада України. Відомості Верховної Ради України. 2003. № 45-46. Cm. 356 .

2. Кодекс торговельного мореплавства України : Закон Украіни від 23 травня 1995 року № 176/95-ВР / Верховна Рада України. Відомості Верховної Ради України. 1995. №.oo 47, 48, 49, 50, 51, 52, cm. 349. URL: https: / / zakon.rada.gov.ua/laws / show / $176 / 95-\%$ D0\% B2\% D1\% 80\#top 


\section{ЮРИАИЧНИЙ ВІСНИК, 2021/5}

3. Кодекс торговельного мореплавства України (КТМУ). Науково-практичний коментар. Коментовані кодекси науково-практичні коментарі до чинного законодавства України - Безкоштовні кодекси та коментарі України - Кодекси України. URL: http://uazakon.ru/ukr/ ktmu/index.htm

4. Конвенція ООН про морське перевезення вантажів від 31 березня 1978 р. (Гамбурзькі правила). База даних «Законодавство України». URL: https: / / zakon.rada.gov.ua / laws / show/995_391\#Text

5. BIMCO. URL: https: / / wrew.bimco.org

6. FONASBA

$U R L:$

https: / / www.fonasba.com / fonasba-mem ber? fbclid=IwAROU6yjkkdM2DYA9vCr. ff7yRBO5EoxlbNbsYVOEv8xeJHvUK8p0 $\overline{5}$ t23xAs

7. Безлюдько I.О. Договір перевезення вантажу повітряним транспортом за иивільним правом України автореф. дис. ... канд. юрид. наук : спеи. 12.00.03 «Цивільне право $і$ иивільний проиес; сімейне право; міжнародне приватне право». Київ, 2005. 20 с.

8. Воронець Н.В. Перевезення вантажів морським транспортом. Протокол. Юридичний інтернет-ресурс. URL: https: / / protocol.ua/ru/perevezennya_ vantagiv_morskim_transportom /

9. Допілка В.О., Балобанов О.О. Міжнародне та національне морське право України і країн ЕС. Навчальний посібник. 2017. $214 c$

10. Конвенція Організаиії Об’єднаних Наиій про морське перевезення вантажів від 31 березня 1978 року. Митна енииклопедія: у 2 m. / відп. ред. І. Г. Бережнюк та ін. Хмельницький : ПП Мельник А.А., 2013. T. $1: A-Л .472$ с.

11. Кузнецьо С.О., Аверочкіна Т.В. Морське право : підручн. Одеса : Фенікс, 2011. $382 \mathrm{c}$.

12. Міжнародне приватне право: Навч. посібник / за ред. В.М. Гайворонського, В.П. Жушмана. Київ : Юрінком Irmep, 2005. $368 \mathrm{c}$.

13. H а у ко в о - $n$ р ак коментар (від 11.10.2011) до статті 133 Кодексу торговельного море- плавства Украӥни. LIGAZAKON. URL: https: / / ips.ligazakon.net / document / KK005973

14. Ольховик Л.А., Мінковський В.В. Форми договору лізингу морського судна. Актуальні проблеми вітчизняної юриспруденції. № 2. T. 2 . 2018. C. 7-10

15. Попов B.A., Рубан O.O. Місие договору чартеру (фрахтування) у изивільному праві України. Юридичний науковий електронний журнал. № $2 / 2021$. С. 92-94.

16. Рябкін Д.А. Основні особливості договорів міжнародного морського перевезення вантажів. Науковий вісник Ужгородського національного університету. 2013. Серія ПРАВО. Bun. 22. 4. I. T. 1 2013. C. 216-219.

17. Тарасенко Л.Л. Договори у сфері оренди транспортних засобів : дис. канд. юрид. наук : 12.00 .03 Львів, 2014. $252 \mathrm{c}$

18. Чубарєв В.Л. Міжнародне приватне право : Навчальний посібник. Київ : Атіка, 2006. 608 c.

19. Babazadeh A.F. Safe Port Clauses: A Comparison of English Law and Azerbaiani Law / / Bakı Dövlat Universiteti Talabo Hbquq Jurnalı / Baku State University Law Review. 2018. No. 7. P. 171

20. Cooke J. Voyage Charters. 4th ed. London, 2014

21. Coghlin T., Baker A., Kenny J., Kimball J.D., Belknap T.H. Time Charters. 7th ed. London, 2014.

22. Davis M. Bareboat Charters. 2nd ed. London, 2005

23. Grime R. Shipping Law. Concise College Texts. London, 1978. P. 80.

24. Lesni C.I. The Ship Owner's Obligation to Ensure Seaworthiness of the Ship-Implicit Obligation of the Ship Owner in the Charter Party / / Contemporary Readings in Law and Social Justice. 2012. Vol. 4. No. 1. P. 563.

25. International Maritime Organization. URL: http: / / www.imo.org / en / About / Pages / Default.aspx

26. Wilson J.F. Carriage of Goods by Sea. London, 1992. P. 4. 